\title{
GAMBARAN PEMERIKSAAN MIKROSKOPIK BASIL TAHAN ASAM PADA PASIEN DIAGNOSA KLINIK LEPRA DI POLI PENYAKIT KULIT DAN KELAMIN DI BLU RSUP PROF. Dr. R. D. KANDOU MANADO
}

\author{
${ }^{1}$ Herlina Soumilena \\ ${ }^{2}$ Standy Soeliongan \\ ${ }^{3}$ Velma Buntuan \\ ${ }^{1}$ Kandidat Skripsi Fakultas Kedokteran Universitas Sam Ratulangi Manado \\ ${ }^{2}$ Bagian Mikrobiologi Fakultas Kedokteran Universitas Sam Ratulangi Manado \\ Email: herlina_soumilena@yahoo.com
}

\begin{abstract}
Leprosy or Hansen Morbus (MH), is a chronic infection of Mycobacterium leprae which mainly affects the skin and nervous system, Mycrobacterium leprae shaped bacillus with a size of 3-8 um x 0.5, acid and alcohol resistant gram-positive as well as some of the factors that affect M.leprae include: duration of contact, closeness, nutritional status, immune status, and environment to establish the diagnosis of leprosy is necessary to do history taking, physical examination, special examination (sensibility and nerves) and laboratory Examination of Acid Bacillus (AFB) staining using 3 different methods, namely staining Thian Hok Tam, Zeihl Neelsen staining, staining Flourokrom.The Goal of this research is To be able to know and do the bacteriological examination in patients with clinical diagnosis of Morbus Hansen Method: The study was a descriptive research study in do in the Skin and Venereal diseases Poly BLU Prof. Dr. R. D. Kandou hospital. Sample management is done at the Laboratory of Microbiology, Faculty of Medicine, University of North Sulawesi Sam Ratulangi This study was done in November 2013-20 January 2014. Results of the study sample was found to be largely male samples 13 samples (65\%) while 7 samples of women (35\%). of 20 samples were examined in the number of patients found positive 11 samples (55\%) and 9 samples negatife (45\%), so the results of this study indicate that more men compared women, of 20 samples examined were found 11 samples showed positive results and 9 negative samples
\end{abstract}

Keywords: mycrobacterium leprae, basil resistant acid, laboratory tests.

\begin{abstract}
Abstrak: Kusta atau Morbus Hansen (MH), adalah infeksi kronis dari Mycobacterium lepraeyang sebagian besar mempengaruhi kulit dan system saraf, Mycrobacterium.leprae berbentuk basil dengan ukuran 3-8 Um x 0,5; tahan asam dan alcohol serta gram positif beberapa faktor yang mempengaruhi M. leprae antara lain: lama kontak, keeratan, status gizi , status imun, dan lingkungan Untuk menetapkan diagnosis penyakit kusta perlu di lakukan anamnesis, pemeriksaan fisik, pemeriksaan khusus (sensibilitas dan saraf) dan pemeriksaan laboratorium Pemeriksaan Basil Tahan Asam (BTA) menggunakan 3 macam metode pewarnaan yaitu pewarnaan Tam Thian Hok, pewarnaan Zeihl Neelsen, pewarnaan Flourokrom. Tujuan: untuk dapat mengetahui dan melakukan pemeriksaan bakteriologi pada pasien dengan diagnosa klinik Morbus Hansen. Metode Penelitian: penelitian merupakan penelitian deskriptif yang di lakukan di Poli penyakit Kulit dan Kelamin BLU RSUP Prof. Dr. R. D. Kandou. Pengelolaan Sampel di lakukan di Laboratorium Mikrobiologi Fakultas Kedokteran Universitas Sam Ratulangi Sulawesi Utara. Penelitian ini di lakukan pada bulan November 2013Januari 2014. Hasil dari 20 Sampel penelitian ditemukan sebagian besar sampel 13 sampel pria (65\%) sedangkan 7 sampel wanita (35\%), dari 20 sampel yang di periksa di temukan jumlah pasien positif 11 sampel (55\%) dan 9 sampel negatif (45\%), jadi dari hasil penelitian ini menunjukan bahwa Pria lebih banyak di bandingkan Wanita, dari 20 sampel yang di periksa ditemukan 11 sampel menunjukan hasil positif dan 9 sampel negatif.
\end{abstract}

Kata kunci: mycrobacterium Leprae, basil tahan asam, pemeriksaan laboratorium. 
Penyakit kusta adalah penyakit kronis yang disebabkan oleh kuman Mycobaceterium leprae yang pertama kali menyerangsusunan syaraf tepi, selanjutnya dapat menyerang kulit,mukosa (mulut), saluran pernapasan bagian atas, system retikulo endotelial, mata, otot, tulang dan testis. ${ }^{1}$

Data dari Organisasi Kesehatan Dunia (WHO) yang di terima dari bebearapa Negara melaporkan bahwa dari 105 negara dan wilayah, prevalensi kusta secara global pada awal tahun 2012 kasus yang terdafatar mencapai 181.941 kasus. Sedangkan jumlah kasus yang terdeteksi selama 2011 adalah 219.075 dibandingkan dengan 228.474 kasus pada tahun 2010. Daerah endemisitas tinggi masih tetap berada di beberapa daerah yaitu di Brazil, Indonesia, Filipina, Republik Demokratik Kongo, India, Madagaskar, Mozambik, Nepal, dan Republik Tanzania. ${ }^{2}$

Menurut Menkes, Sejak tahun 2000. Program pengendalian penyakit kusta Nasional melaporkan 17,000-18,000 kasus baru setiap tahun dan belum ada kecenderungan menurun.Proporsi kasus baru kusta MB (Multi Basiler/kuman banyak). Indonesia masih merupakan negara ketiga di dunia dan kedua di Asia Tenggara sebagai negara dengan kasus baru kusta paling banyak. ${ }^{3}$

Dinas Kesehatan Provinsi Sulawesi Utara mencatat sepanajang tahun2012 ada 400-an penderita kusta yang tersebar di 15 kabupaten/kota. Kota Bitung adalah daerah dengan penderita kusta terbanyak yaitu sekitar 80-an orang. Kemudian disusul Manado dan Bolaang Mongondow. Kusta yang ditemukan Tahun 2012 sebanyak 425 kasus, yang berobat sampai dengan sekarang 494 orang dengan jenis kusta yang paling banyak adalah tipe basah dengan jumlah 373 kasus. ${ }^{4}$

M. Lepra yang solid atau utuh dianggap kuman yang hidup, sedangkan yang fragmented atau nonsolid dianggap kuman yang mati $M$. Leprae hidup di luar tubuh dapat hidup 2-9 hari. ${ }^{5}$

Pemeriksaan Basil Tahan Asam (BTA) menggunakan 3 macam metode pewarnaan yaitu:Pewarnaan Tan Thiam Hok, Pewarnaan Zeihl Neelsen, Pewarnaan Flourokrom. Pada pemeriksaan dengan mengguanakan metode fluorokrom pada pemeriksaan di bawah mikroskop tidak memerlukan pembesaran 1000x hal ini sanggat bermanfaat pada laboratorium dengan jumlah sampel yang banyak. Penggunaan pewarnaan ini di laboratorium Indonesia tidak lah mudah karena memiliki biaya yang tinggi untuk penyediaan mikroskop fluoresens, sehingga DOTS (Direct Observed Treatment Shortcourse Chemotherapy) yang di rekomendasikan WHO dan telah di lakukan di Indonesia, selain adanya gejala khas di gunakan cara pewarnaan BTA Ziehl Neelsen untuk penentuan di mulainya pengobatan. ${ }^{6}$

Kusta jika tidak ditanggani akan menyebabkan perubahan fisik, social, dan psikologis yang berupa ketidak mampuan dan keterbatasan. Keadaan ini secara epidemiologis terjadi peningkatan prevalensi kusta dari tahun ke tahun.Sehubung dengan hal tersebut penulis tertarik untuk meneliti mengenai Gambaran Pemeriksaan Mikroskopik Basil Tahan Asam pada pasien yang didiagnosa klinik Morbus Hansen di Manado.

\section{METODE PENELITIAN}

Penelitian ini merupakan penelitian deskriptif melalui penelitian yang dilakukan di laboratorium mikrobiologi secara mikroskopik pada Basil Tahan Asam (BTA) dan Pewarnaan basil Tahan Asam (BTA) di laboratorium mikrobiologi Fakultas Kedokteran Universitas Sam Ratulangi Manado periode November 2013-Februari 2014.

\section{HASIL PENELITIAN}

Pasien Lepra atau Kusta yang didiagnosa klinik yang datang berobat di Poli Penyakit Kulit dan Kelamin Blu Prof Dr R D Kandou Manado sebanyak 20 sampel kemudian di lakukan pengambilan sampel dari serum cuping telingga. Berdasrkan Jenis kelamin didapatkan hasil 13 orang (65\%) pria dan 7 orang (35\%) wanita. Penelitian ini menunjukan 11 sampel positif (55\%) dan 9 sampel negatif (45\%) 
Tabel 1. Distribusi sampel menurut jenis kelamin

\begin{tabular}{lcc}
\hline Jenis Kelamin & $\begin{array}{c}\text { Jumlah } \\
\text { Penderita }\end{array}$ & Presentase \\
\hline Pria & 13 & $65 \%$ \\
Wanita & 7 & $35 \%$ \\
Jumlah & 20 & 100 \\
\hline
\end{tabular}

Tabel 1 menunjukan 20 sampel dimana terdiri dari 13 sampel berjenis kelamin LakiLaki (65\%) dan 9 sampel berjenis kelamin perempuan (35\%)

Tabel 2. Hasil pemeriksaan laboratorium basil tahan asam pada pasien diagnosa klinik lepra.

\begin{tabular}{|c|c|c|c|}
\hline \multirow[t]{2}{*}{ NO } & \multirow[t]{2}{*}{ SAMPEL } & \multicolumn{2}{|c|}{$\begin{array}{c}\text { HASIL PEMERIKSAAN } \\
\text { BASIL TAHAN ASAM } \\
\text { (BTA) }\end{array}$} \\
\hline & & $(+)$ & $(-)$ \\
\hline 1 & 1 & + & \\
\hline 2 & 2 & & - \\
\hline 3 & 3 & & - \\
\hline 4 & 4 & + & \\
\hline 5 & 5 & & - \\
\hline 6 & 6 & & - \\
\hline 7 & 7 & + & \\
\hline 8 & 8 & + & \\
\hline 9 & 9 & + & \\
\hline 10 & 10 & + & \\
\hline 11 & 11 & + & \\
\hline 12 & 12 & + & \\
\hline 13 & 13 & + & \\
\hline 14 & 14 & + & \\
\hline 15 & 15 & + & \\
\hline 16 & 16 & & - \\
\hline 17 & 17 & & - \\
\hline 18 & 18 & & - \\
\hline 19 & 19 & & - \\
\hline 20 & 20 & & - \\
\hline
\end{tabular}

Tabel 2 terdapat 20 sampel dimana dari 20 sampel yang di diagnosa klinik Lepra 11 sampel memiliki hasil yang positif sedangkan 9 sampel meiliki hasil yang negatif.

\section{BAHASAN}

Penelitian ini di lakuakan pada pasien dengan diagnosa klinik lepra sebanyak 20 sampel, yang di lakukan pada serum cuping telinga penderita Morbus Hansen di Poli Penyakit Kulit dan Kelamin di BLU RSUP Prof. Dr. R. D. Kandou, periode November 2013 sampai Januari 2014 didapatkan 20 sampel penelitian. Adapun pemeriksaan yang di lakukan yaitu pemeriksaan dan pewarnaan Basil Tahan asam (BTA).

Dari Tabel 1 diistribusi sampel menurut jenis kelamin, penderita Morbus Hansen terbanyak pada penelitian adalah Laki-Laki yaitu 13sampel atau 65\% dari total sampel. Sedangkan sampel Perempuan 7 sampel atau 35\% dari total Sampel. Hasil ini sesuai dengan kepustakaan yang menyebutkan bahwa penderita kusta lebih banyak terjadi pada laki-laki, yaitu sebanyak 70,5\%, sedangkan pada perempuan terdapat 29,5\% yang dilakukan di Kecamatan Sarang Kabupaten Rembang. Hal ini bukan disebabkan lamanya masa sakit tapi perbedaan antara angka insidensi. ${ }^{7}$ Hasil penelitian yang telah di lakukan ini juga di dukung oleh kepustakaan lain yang dilakukan di Divisi Kusta URJ Penyakit Kulit dan Kelamin RSUD Dr. Soetomo Surabaya Periode 2004-2006 berdasarkan jenis kelamin, jumlah total penderita kusta baru pada laki-laki sebanyak 652 orang (69,2\%). Jumlah ini juga mengalami sedikit peningkatan dibandingkan tahun 2001-2003 yakni sebanyak 605 orang.Jumlah penderita kusta yang berjenis kelamin laki-laki pada penelitian ini hampir dua kali lipat lebih banyak daripada penderita kusta yang berjenis kelamin wanita yaitu sebanyak 299 orang. Perbandingan itu sesuai dengan rasio prevalensi penderita kusta laki-laki dibandingkan wanita pada penelitian di negaranegara endemik kusta yaitu kurang lebih 2:1.

Keadaan tersebut kemungkinan disebabkan karena laki-laki cenderung lebih sering beraktivitas di luar rumah sehingga sering terpapar dengan penderita yang menjadi sumber infeksi sehingga risiko tertular kusta lebih besar dari pada laki-laki. ${ }^{8}$

Hasil ini juga di dukung oleh kepustakaan yang menyebutkan bahwa pada pasien lepra dewasa umumnya jumlah pasien laki-laki lebih banyak daripada wanita, dengan rasio 2:1.Distribusi tersebut 
kemungkinan di pengaruhi oleh faktor lingkungan atau biologi. Pola hidup laki-laki menyebabkan mereka memiliki risiko lebih tinggi untuk terpajan penyakit lepra. ${ }^{1}$

Pada pemeriksaan yang dilakukan terhadap 20 sampel yang di teliti, di temukan bahwa 11 sampel pasien dengan diagnosa klinik lepra menunjukan hasil yang positif dan 9 sampel menunjukan hasil yang Negaitif. Dari 20 sampel yang di periksa di laborratorium dengan diagnosa klinik Lepra memiliki hasil yang kemungkinan berbeda dengan cara pemeriksaan secara laboratorium, hasil negatif pada pemeriksaan mikroskopik mungkin saja dapt terjadi karena kesalahan pada saat pengambilan sampel dan pewarnaan. hal ini sesuai dengan kepustakaan yang menyebutkan bahwa angka kesalahan baca adalah angka kesalahan laboratorium yang menyatakan persentase kesalahan pembacaan slide/sediaan yang di lakukan oleh laboratorium rujukan lain. Angka kesalahan laboratorium pemeriksaan pertama. Selain angka kesalahan laboratorium yang terjadi, kesalahan juga dapat berupa tidak memadainya kualitas sediaan, yaitu terlalu tebal atau tipisnya sediaan, pewarnaan, ukuran, kerataan, kebersihan dan kualitas specimen. ${ }^{9}$

\section{SIMPULAN}

Dari 20 sampel yang diperiksa ditemukan 11 sampel positif terdapat Basil Tahan Asam dan 9 sampel menunjukan hasil yang negative,Pria lebih banyak di bandingkan dengan wanita.

\section{DAFTAR PUSTAKA}

1. Selum, Wahyuni CU, Risiko Kecatatan pada Ketidakteraturan Berobat Penderita Kusta di Kabupaten Pamekasan Provinsi Jawa Timur.The Indonesian Journal of Public Health, 2013 - 210.57.222.46

2. Worl Health Organization, Global Leprosy situation today [online]. 2012. Availble at: URL: http://www.who.int/ mediacentre/factsheets/fs101/en/

3. DEPKES RI Nasional Eliminasi Kusta (ANEK) [online]. 2005. http://www. depkes.go.id/index.php?vw=2\&id=1188

4. 400-an Warga Sulawesi Utara Terkena Kusta [online]. http://www.portalkbr.com/ nusantara/sulawesi/2493544_4445.html

5. Robertuji, Hasrul Harun. Kuman Tahan Asam. Dalam: Saputra L, editor. Buku Ajar Mikrobiologi Kedokteran. Revisised. Fakultas Kedokteran Universitas Indonesia. Jakarta: Binarupa Aksara Publisher, 227-38

6. Karuniawati A, Risdiyani E, Nilawati S, Prawoto, Rosana Y, Alisyabahna B, dkk. Perbandingan Tan Thiam Hok, Ziehl Neelsen dan Flurokrom Sebagai Metode Pewarnaan Basil Tahan Asam Untuk Pemeriksaan Mikroskopik Sputum. Makara Kesehatan. Juni 2005;9:29-33.

7. Jaiman SPH, Tjhjadi W, Sihadi, Profil Penderita Kusta di Kecamatan Saran Kabupaten Rembang 1996. Penelitian. Kesehatan. 2002;22

8. Putra IGND, Fauzi N, Agusni I, Kecacatan Pada Penderita Kusta Baru di Devisi Kusta URJ Penyakit Kulit dan Kelamin RSUP Dr. Soetmo Suraabaya Periode 2004-2006.

9. Martiningrum, RZ. Determinan Error Rate Puskesmas Rujukan Mikroskopis (PRM ) dan Puskesmas Pelaksana Mandiri (PPM) Di Kabupaten Jember [Skripsi]. Fakultas Kesehatan Masyarakat Universitas Jember; 2013; h.41. 